\title{
Expanded Granular Sludge Bed (EGSB) Reactor Treating Actual Domestic Wastewater: Temperature Influence
}

\author{
Chunjuan Dong $*, 1$ \\ ${ }^{* 1}$ Department of Environmental Engineering \\ Taiyuan University \\ Taiyuan, 030009, China \\ E-mail:chunjuand@126.com
}

\author{
Zhaoyu Geng ${ }^{2}$, Yanxia Wang ${ }^{1}$ \\ ${ }^{2}$ Department of Drainage Management \\ City and Town Management Committee of Taiyuan \\ Taiyuan, 030024, China \\ E-mail: zhygeng@sina.com
}

\begin{abstract}
To demonstrate the feasibility of using expanded granular sludge bed (EGSB) reactor as the single reactor for the treatment of domestic treatment when the temperature fluctuates between $15^{\circ} \mathrm{C}$ (winter) and $26^{\circ} \mathrm{C}$ (summer), the effects of operation temperature $\left(15^{\circ} \mathrm{C}, 26^{\circ} \mathrm{C}\right.$ ) on the performance, methanogenic activity and granular size distribution were investigated in this paper. The results indicated that the EGSB reactor could keep very high COD removal efficiencies $(80.2 \%-82.3 \%)$ at $0.5 \mathrm{~h}-0.8 \mathrm{~h}$ HRT when treating actual domestic wastewater at ambient temperature $\left(15^{\circ} \mathrm{C}\right.$ to $\left.26^{\circ} \mathrm{C}\right)$. The $\mathrm{COD}$ average removal efficiencies would decrease to only $78.3 \%$ and/or $72.3 \%$ for $0.4 \mathrm{~h}$ HRT and/or 1.0-3.0h HRT. Although enhancing $V_{u p}$ could increase COD removal efficiency, the increasing quantity was comparatively limited. When using EGSB reactor to treat actual domestic wastewater at ambient temperature $\left(15^{\circ} \mathrm{C}\right.$ $26^{\circ} \mathrm{C}$ ), the $15-24 \mathrm{~L} \cdot \mathrm{h}^{-1}$ influent flow and $3.0 \mathrm{~m} \cdot \mathrm{h}^{-1} V_{u p}$ was suitable. At $26^{\circ} \mathrm{C}$, the SMA was not decreased. But at $15^{\circ} \mathrm{C}$, the SMA was distinctly decreased, however which could resume at $35{ }^{\circ} \mathrm{C}$. Low temperature would compel the microorganisms to get together as soon as possible. Compared with $26^{\circ} \mathrm{C}$, the average size of the granules was increased from $0.9 \mathrm{~mm}$ to $1.0 \mathrm{~mm}$ at $15^{\circ} \mathrm{C}$.
\end{abstract}

Keywords -- EGSB reactor; domestic wastewater; temperature; SMA; granules; size distribution

\section{INTRODUCTION}

Traditionally, anaerobic digestion has been applied to medium and high strength wastewater. In recent years, growing efforts have been applied in order to establish the feasibility of high rate anaerobic digestion to the treatment of diluted effluent. But many low strength wastewaters are discharged at low ambient temperatures, including domestic wastewater and a large variety of industrial wastewater.

Microorganisms are classified into 'temperature classes' on the basis of the optimum temperature and the temperature span in which the species are able to grow and metabolize. But the overlapping growth temperature ranges indicate that there isn't a clear boundary between these classic groups of psychrophilic, mesophilic and thermophilic microorganisms.
However, under psychrophilic conditions, chemical and biological reactions proceed much slower than under mesophilic conditions. Moreover, a strong temperature effect on the maximum substrate utilization rates of microorganisms has been observed by many researchers.

One of the major successes in the development of anaerobic wastewater technology was the introduction of highrate reactors in which biomass retention and liquid retention are uncoupled. This feature comprises a crucial issue for the treatment of low(er) strength wastewater. Obviously, the low COD influent will result in low substrate levels inside the reactor and also in a low biogas production rate. And for the well-known Upflow Anaerobic Sludge Bed (UASB) reactor, this implies low mixing intensities in the reactor and consequently in a poor substrate-biomass contact. Thus, Practically all full-scale applications of anaerobic wastewater treatment so far are restricted to wastewater with temperatures exceeding $18^{\circ} \mathrm{C}^{[1]}$.

Because temperature strongly affects the rates of the anaerobic conversion processes, some essential improvements have to be made in the conventional design of high-rate reactors to enable their application under sub-optimal temperatures and for very low strength wastewater. The results of experiments into optimizing the contact of sludge and wastewater in UASB reactors, led to the development of an advanced reactor design, namely the expanded granular sludge bed (EGSB) reactor ${ }^{[2-3]}$. The EGSB system uses exclusively granular sludge, and meanwhile through applying effluent recycle and/or using tall reactors, the upflow velocities $\left(V_{u p}\right)$ applied in the EGSB system can range from 4 to $10 \mathrm{~m} . \mathrm{h}^{-1}$. But so far, for domestic wastewater treatment when the temperature fluctuates between $15^{\circ} \mathrm{C}$ (winter) and $25^{\circ} \mathrm{C}$ (summer), a staged reactor is recommended. At higher temperatures $\left(>20^{\circ} \mathrm{C}\right)$, a single reactor could suffice for raw sewage ${ }^{[4-5]}$.

The objectives of this research are to demonstrate the feasibility of using EGSB as the single reactor for the treatment of domestic treatment when the temperature fluctuates between $15^{\circ} \mathrm{C}$ (winter) and $26^{\circ} \mathrm{C}$ (summer). The performance of EGSB reactor at ambient temperature and the effect of temperature were reviewed. Meanwhile, to confirm the feasibility of using EGSB to stably treat domestic wastewater at ambient 
temperature and to suggest the prevalence of psychrotolerant organisms, the granular characteristics, such as methanogenic activity, granular size distribution, were also analyzed.

\section{MATERIALS AND METHODS}

\section{A. Reactor Set-up}

The research was carried out in a lab-scale EGSB reactor. The $2.3 \mathrm{~m}$ height EGSB reactor was an acrylic column with a conical-shaped bottom, a working volume of $12 \mathrm{~L}$, an internal diameter of $10 \mathrm{~cm}$. The wastewater used as influent to the reactor was collected from the residential area of Tai-Yuan University with $88-952 \mathrm{mg} . \mathrm{L}^{-1} \mathrm{COD}, 146-391 \mathrm{mg} . \mathrm{L}^{-1}$ alkalinity, 25-72 mg.L $\mathrm{L}^{-1} \mathrm{NH}_{3}-\mathrm{N}$ and 80-320 mg.L $\mathrm{L}^{-1} \mathrm{SS}$, respectively. Some trace metals for $\mathrm{Fe}, \mathrm{Co}$, Ni were added. A schematic diagram of the EGSB reactor used is presented in Fig.1.

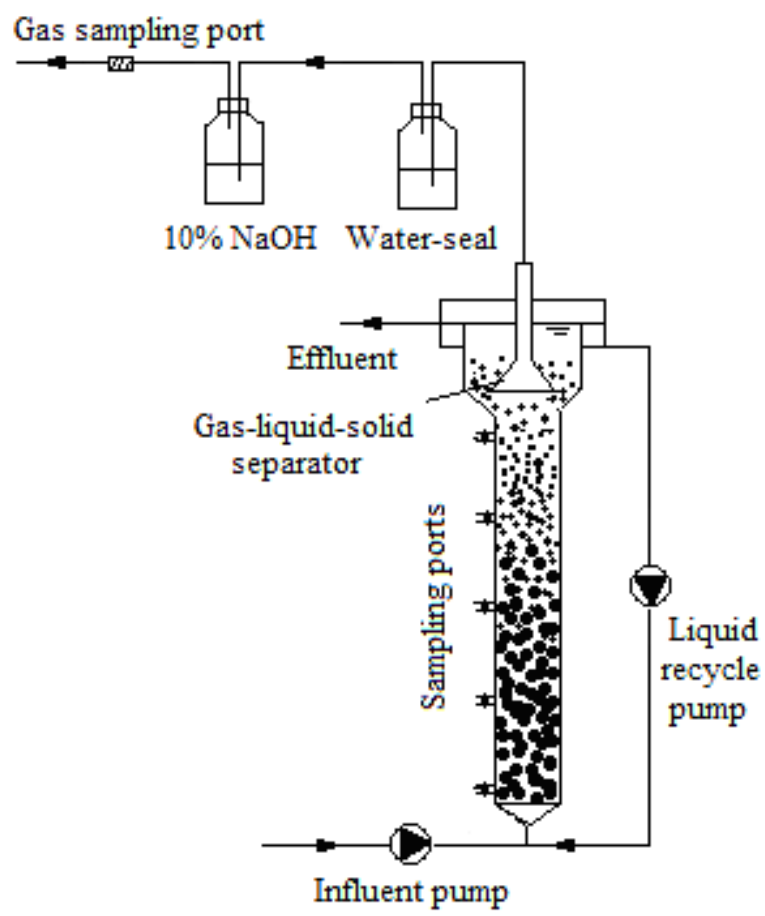

Fig.1 Schematic diagram of the experimental EGSB reactor

\section{B. Seed Sludge}

The inoculum used in this experiment was municipal digestion sludge and little granules. The anaerobic digestion sludge was obtained from the dehydrated sludge from an anaerobic digester at YangJiaBu Wastewater Treatment Plant, TaiYuan (its activity was resumed before seeding into the EGSB reactor). And the granular sludge was obtained from a pilot-plant anaerobic EGSB reactor treating actual brewage wastewater for two years. Moreover, the granular sludge was deposited without any nutrients addition for two years under ambient temperature. Thus, the granules were loose. The steady-state operation EGSB reactor had $25.4 \mathrm{~g} . \mathrm{L}^{-1} \mathrm{gSS} \cdot \mathrm{L}^{-1}$ biomass concentration and $0.77 \mathrm{VSS} / \mathrm{SS}$, respectively.

\section{Analytical Methods}

Effluent was collected and centrifuged at 4000rpm for
3 min with a centrifuge (80-2B, ANTING). And then the supernatant was used for further analysis. The measurement of COD, MLSS and MLVSS were according to the Chinese Standard Methods for Water and Wastewater Monitoring and analytical methods ${ }^{[6]}$. Specific methanogenic activity test was accomplished as described by Zhao et $\mathrm{al}^{[7]}$. Each analysis was carried out in triplicate and the results presented are the mean values.

\section{Operating strategy}

The operation process of the EGSB reactor was separated into two stages. First, at stage I, to investigate performance of the EGSB reactor treating actual domestic wastewater, the COD removal efficiency was investigated with varied influent flow and varied OLR, in which the term "performance of the EGSB reactor" was defined as the COD removal efficiency(\%) $=\frac{C O D_{\text {in }}-C O D_{\text {eff }}}{C O D_{\text {in }}} \times 100$. The influent flow was varied between 4L.h ${ }^{-1}$ and $30 \mathrm{~L} \cdot \mathrm{h}^{-1}$, and meanwhile with the influent COD concentration of $84-952 \mathrm{mg} . \mathrm{L}^{-1}$, the OLR was fluctuated between $1.99 \mathrm{kgCOD} \cdot \mathrm{m}^{-3} \cdot \mathrm{d}^{-1}$ and $57.12 \mathrm{kgCOD} \cdot \mathrm{m}^{-3} \cdot \mathrm{d}^{-1}$. And then at stage II, to investigate the temperature influence on the EGSB performance, the EGSB reactor was operated at $26^{\circ} \mathrm{C}$ and $15^{\circ} \mathrm{C}$, respectively, and the investigated influent flow was 9L.h ${ }^{-1} 、 15 \mathrm{~L} . \mathrm{h}^{-1} 、 24 \mathrm{~L} \cdot \mathrm{h}^{-1}$ with $3.0 \mathrm{~m} \cdot \mathrm{h}^{-1} V_{u p}$. Moreover, for $15^{\circ} \mathrm{C}$ low temperature and 9L.h ${ }^{-1}$ low influent flow, the $V_{u p}$ was increased from $3.0 \mathrm{~m} \cdot \mathrm{h}^{-1}$ to $4.2 \mathrm{~m} \cdot \mathrm{h}^{-1}$ to investigate the performance of the EGSB reactor. The Specific methanogenic activity and size distribution of the granules in the EGSB at $26^{\circ} \mathrm{C}$ and $15^{\circ} \mathrm{C}$ was also assayed, respectively. The granules samples taken from the $26^{\circ} \mathrm{C}$ EGSB reactor was used to assay the Specific methanogenic activity (SMA) at both $26^{\circ} \mathrm{C}$ and $35^{\circ} \mathrm{C}$ (expressed as $26^{\circ} \mathrm{C}$ from $26^{\circ} \mathrm{C}$ and $35^{\circ} \mathrm{C}$ from $26^{\circ} \mathrm{C}$, respectively). And the SMA assays of the granules sample at $15^{\circ} \mathrm{C}$ EGSB reactor were preformed at both $15^{\circ} \mathrm{C}$ and $35^{\circ} \mathrm{C}$ (expressed as $15^{\circ} \mathrm{C}$ from $15^{\circ} \mathrm{C}$ and $35^{\circ} \mathrm{C}$ from $15^{\circ} \mathrm{C}$, respectively).

\section{RESULTS AND DISCUSSION}

\section{A. Performance of reactor at ambient temperature}

The EGSB reactor treating actual domestic wastewater was performance at ambient temperature (between $13^{\circ} \mathrm{C}$ and $26^{\circ} \mathrm{C}$ ) along with the change of the climate temperature for about six months. Fig.2 showed the variation in COD in the reactor influent and effluent as well as the removal efficiency. Accordingly, the changes of the influent flow and OLR were depicted in Fig.3 and Fig.4.

With 84-952mg.L ${ }^{-1}$ influent COD concentration, the EGSB reactor could attain average COD removal efficiency of $79.5 \%$ (fluctuating between $61 \%$ and $93 \%$ ). Except for initial stages of about days 15 (with higher effluent COD concentration, and high to $180 \mathrm{mg}^{-\mathrm{L}^{-1}}$ ), the effluent COD concentrations could keep below 100mg. $\mathrm{L}^{-1}$ for subsequent about 5 months stable operation stages. Even for the distinct influent COD fluctuation of $179 \mathrm{mg} . \mathrm{L}^{-1} \rightarrow 952 \mathrm{mg} . \mathrm{L}^{-1} \rightarrow 300 \mathrm{mg} . \mathrm{L}^{-1}$ (at days $85 \rightarrow$ days 87 
$\rightarrow$ days 89 ), the effluent COD concentrations were very stable and the corresponding COD values were $38 \mathrm{mg} . \mathrm{L}^{-1} \rightarrow 68 \mathrm{mg} . \mathrm{L}^{-1}$ $\rightarrow 40 \mathrm{mg} . \mathrm{L}^{-1}$, which indicated that the performance of the EGSB reactor treating actual domestic wastewater at ambient temperature was very well and stable.

For about six months, the EGSB reactor undergo a topmost OLR value of $57.1 \mathrm{kgCOD} \cdot \mathrm{m}^{-3} \cdot \mathrm{d}^{-1}$ and an undermost OLR value of $2.0 \mathrm{kgCOD} \cdot \mathrm{m}^{-3} \cdot \mathrm{d}^{-1}$, and the effluent COD concentrations were only $68.0 \mathrm{mg} . \mathrm{L}^{-1}$ (only $0.4 \mathrm{~h} \mathrm{HRT}$ ) and $62 \mathrm{mg}^{-\mathrm{L}^{-1}}$ (with $3.0 \mathrm{~h}$ HRT), respectively, and which indicated that the EGSB reactor had very strong supporting OLR shock ability when treating actual domestic wastewater at ambient temperature.

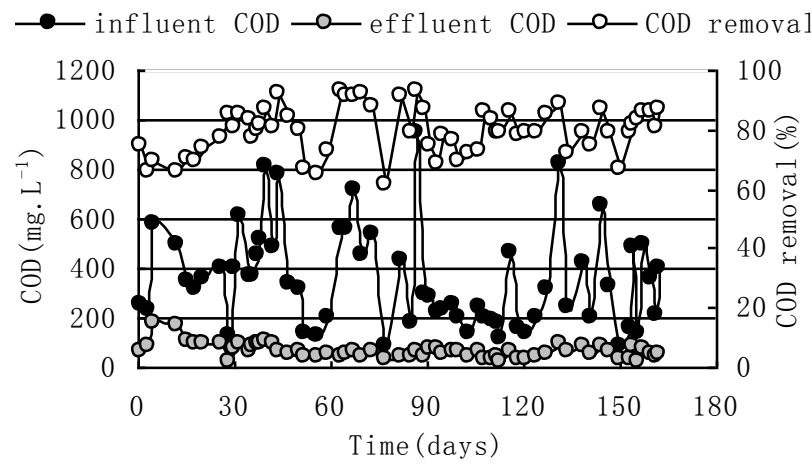

Fig.2. influent and effluent COD and COD removal changes

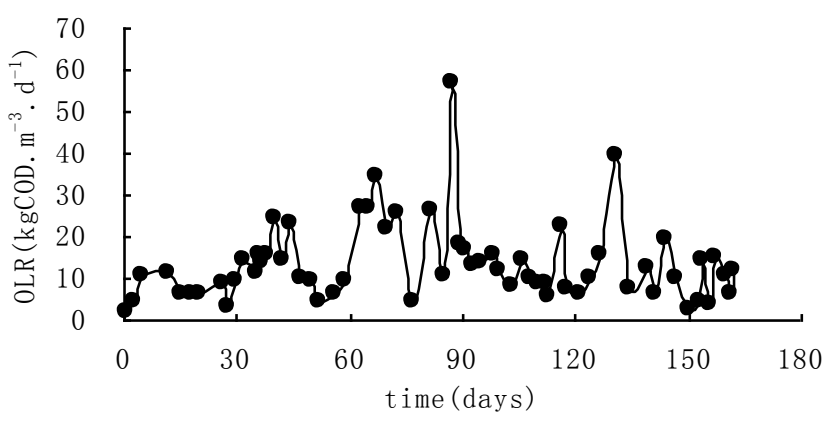

Fig.3. influent OLR changes

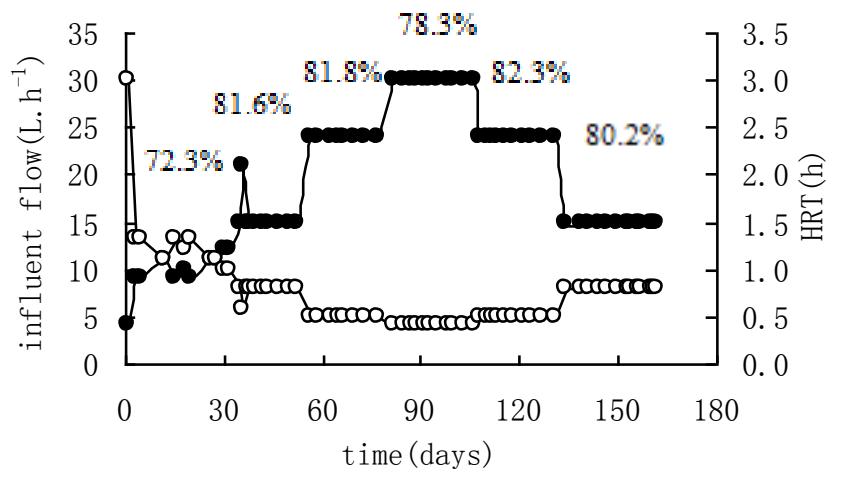

Fig.4. influent flow and HRT changes

At the initial stages of about 15 days, the performance of the EGSB was not stable. At day 1 , only with $4 \mathrm{~L} \cdot \mathrm{h}^{-1}$ influent flow (249mg. $\mathrm{L}^{-1}$ influent COD concentration), the COD removal was only $75 \%$. And with gradually increasing influent flow to $11 \mathrm{~L} . \mathrm{h}^{-1}$ and COD concentration to $575 \mathrm{mg} . \mathrm{L}^{-1}$, the COD removal had a little decreasing (to 69\%). But subsequently with gradually increasing influent flow $\left(15 \mathrm{~L} \cdot \mathrm{h}^{-1} \rightarrow 24 \mathrm{~L} \cdot \mathrm{h}^{-1} \rightarrow 30 \mathrm{~L} \cdot \mathrm{h}^{-1}\right)$, the COD removal efficiencies began to increase and the average COD removal efficiencies were $81.6 \%, 81.8 \%$ and $78.3 \%$, respectively, and which indicated that the EGSB reactor could keep very high COD removal at quite low HRT (only $0.4 \mathrm{~h}-0.8 \mathrm{~h})$ when treating actual domestic wastewater at ambient temperature. Moreover, as showed in Fig.4, when the HRT was between $0.8 \mathrm{~h}$ and $0.5 \mathrm{~h}$, the EGSB reactor could attain $80.2 \%-82.3 \%$ high average COD removal efficiencies. However, only $78.3 \%$ and $72.3 \%$ average COD removal could attain for $0.4 \mathrm{~h}$ HRT and 1.0-3.0h HRT. Thus, for the EGSB reactor treating actual domestic wastewater at ambient temperature, the high influent flow of 15-24L.h ${ }^{-1}$, low HRT of $0.5-0.8 \mathrm{~h}$ and high OLR of 4.2-57.1 $\mathrm{kgCOD} \cdot \mathrm{m}^{-3} \cdot \mathrm{d}^{-1}$ were suitable.

\section{B. COD removal for varied performance temperature}

To investigate the temperature influence on performance, the EGSB reactor was operated at $26^{\circ} \mathrm{C}$ and $15^{\circ} \mathrm{C}$, respectively, and synchronously the investigated influent flow was $9 \mathrm{~L} . \mathrm{h}^{-1}$ 、 $15 \mathrm{~L} . \mathrm{h}^{-1} 、 24 \mathrm{~L} . \mathrm{h}^{-1}$. The results were presented in table 1.

Table 1 temperature influence on performance of reactor

\begin{tabular}{|c|c|c|c|c|}
\hline $\begin{array}{c}\text { Temperature } \\
\left({ }^{\circ} \mathrm{C}\right)\end{array}$ & $\begin{array}{c}\text { Influent } \\
\text { flow } \\
\left({\left.\mathrm{L} . \mathrm{h}^{-1}\right)}^{-1}\right.\end{array}$ & $\begin{array}{c}\mathrm{HRT} \\
(\mathrm{h})\end{array}$ & $\begin{array}{c}V_{u p} \\
\left(\mathrm{~m} . \mathrm{h}^{-1}\right)\end{array}$ & $\begin{array}{c}\text { COD } \\
\text { removal } \\
(\%)\end{array}$ \\
\hline 26 & 15 & 0.8 & 3.0 & 83.9 \\
\hline 15 & 15 & 0.8 & 3.0 & 81.4 \\
\hline 26 & 24 & 0.5 & 3.0 & 84.7 \\
\hline 15 & 24 & 0.5 & 3.0 & 81.9 \\
\hline 26 & 9 & 1.3 & 3.0 & 86.0 \\
\hline 15 & 9 & 1.3 & 3.0 & 75.0 \\
\hline 15 & 9 & 1.3 & 4.2 & 79.0 \\
\hline
\end{tabular}

At $26^{\circ} \mathrm{C}$, for $9 \mathrm{~L} . \mathrm{h}^{-1} 、 15 \mathrm{~L} \cdot \mathrm{h}^{-1} 、 24 \mathrm{~L} \cdot \mathrm{h}^{-1}$ influent flow, the EGSB reactor could all have high COD removal efficiencies of $86.0 \% 、 83.9 \% 、 84.7 \%$. At $15^{\circ} \mathrm{C}$, the EGSB could still have high COD removal efficiencies of $81.4 \%$ and $81.9 \%$ for $15 \mathrm{~L} . \mathrm{h}$ ${ }^{1}$ and $24 \mathrm{~L} . \mathrm{h}^{-1}$ influent flow, but only had $75.0 \%$ COD removal for 9L.h ${ }^{-1}$ influent flow. And subsequently, through increasing $V_{u p}$ form $3.0 \mathrm{~m} \cdot \mathrm{h}^{-1}$ to $4.2 \mathrm{~m} \cdot \mathrm{h}^{-1}$, the COD removal efficiency could increase from $75.0 \%$ to $79.0 \%$, but still not up to $80.0 \%$. The low temperature could decrease the COD removal. But for higher influent flow (following higher OLR), the decreasing degree of COD removal efficiencies was not distinct. To the contrary, for low influent flow to 9L.h ${ }^{-1}$ (following lower OLR), the decreasing extent of COD removal was high to $11 \%$.

Although enhancing $V_{u p}$ could strengthen the mass transfer effect and then increase COD removal efficiency, the increasing quantity was comparatively limited. Thus, when using EGSB reactor to treat actual domestic wastewater at ambient temperature $\left(15^{\circ} \mathrm{C}-26^{\circ} \mathrm{C}\right), 15-24 \mathrm{~L} \cdot \mathrm{h}^{-1}$ influent flow and $3.0 \mathrm{~m} \cdot \mathrm{h}^{-1} V_{u p}$ was suitable, and only $0.5-0.8 \mathrm{~h}$ HRT was employed, above $80 \%$ COD removal could attain. 


\section{SMA for varied performance temperature}

Afterwards, the effects of low temperature on specific methanogenic activity (SMA) were explored. The experiments need to take on two purposes, one was to review the changes of SMA along with the operation temperature changes from $26^{\circ} \mathrm{C}$ to $15^{\circ} \mathrm{C}$, and the other was to compare the difference of SMA between $35^{\circ} \mathrm{C}$ and $26^{\circ} \mathrm{C}$ or $15^{\circ} \mathrm{C}$, and the SMA changes was presented in Fig.5.

Compared with " $26^{\circ} \mathrm{C}$ from $26^{\circ} \mathrm{C}$ ", the SMA of " $15^{\circ} \mathrm{C}$ from $15^{\circ} \mathrm{C}$ " was decreased distinctly. If we defined the slope of the SMA curve (the steepest sect) as " $\gamma$ ", the values of $\gamma$ for " $15^{\circ} \mathrm{C}$ from $15^{\circ} \mathrm{C}$ " and " $26^{\circ} \mathrm{C}$ from $26^{\circ} \mathrm{C}$ " were 12.7 and 28.8 , respectively. But the values of $\gamma$ for " $35^{\circ} \mathrm{C}$ from $15^{\circ} \mathrm{C}$ " and “35 ${ }^{\circ} \mathrm{C}$ from $26{ }^{\circ} \mathrm{C} "$ were almost equal (29.8 and 30.9, respectively). Which adequately showed that low temperature was not restrained the SMA of the granules, $26^{\circ} \mathrm{C}$ operation temperature could ensure high SMA, and the SMA at $15^{\circ} \mathrm{C}$ had the possibility to be increased. Perhaps enhancing $V_{u p}$ was an effective method, and moreover optimizing characteristic of the granules was also another choice.

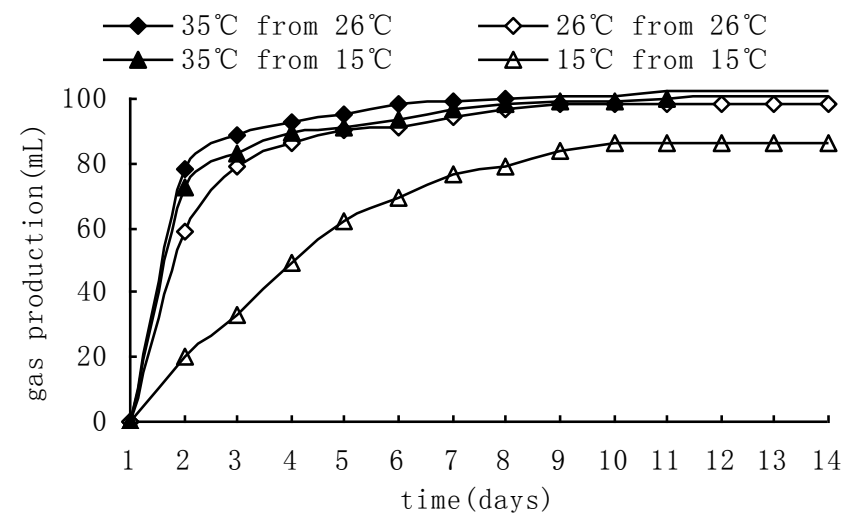

Fig.5. SMA changes of granules for $26^{\circ} \mathrm{C}$ and $15^{\circ} \mathrm{C}$ reactor

\section{Size distribution for varied performance temperture}

When operation temperature gradually decreased from $26^{\circ} \mathrm{C}$ to $15^{\circ} \mathrm{C}$, the granules were taken out from the EGSB reactor to investigate the changes of granules size distribution (presented in Fig.6).

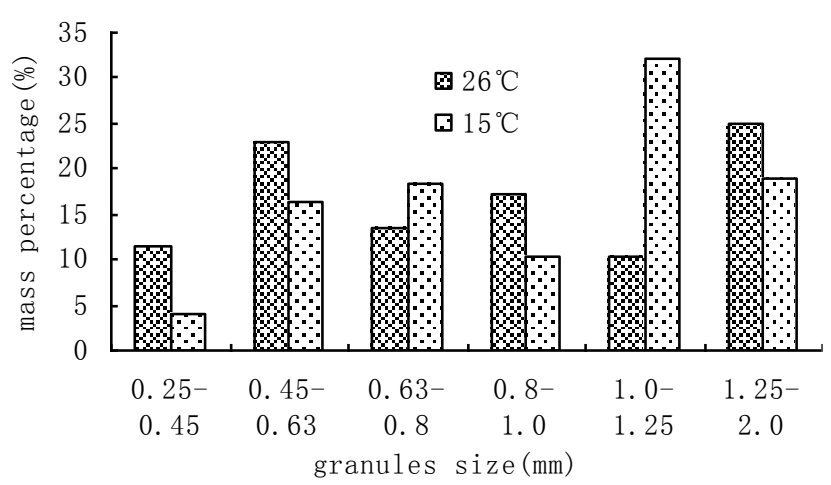

Fig.6. size distribution of granules for $26^{\circ} \mathrm{C}$ and $15^{\circ} \mathrm{C}$ reactor

Compared with $26^{\circ} \mathrm{C}$ operation condition, the average size of the granules was increased from $0.9 \mathrm{~mm}$ to $1.0 \mathrm{~mm}$ at $15^{\circ} \mathrm{C}$, in which the average size of the granules was calculated in this case through following formula: $d_{\text {average }}=\frac{\sum d_{i} p_{i}}{100}$. Mass percentage of $0.25-0.45 \mathrm{~mm}$ granules was decreased from $11.4 \%$ to $4.0 \%$, and synchronously the granules with $\mathrm{d}>1.25 \mathrm{~mm}$ had a decreasing range of $5.9 \%$ (from $24.9 \%$ to $19.0 \%)$. The granules were still distributed in such size range as $0.25-1.25 \mathrm{~mm}$, but low temperature caused the mass percentage of the $0.25-1.25 \mathrm{~mm}$ granules increase from $63.7 \%$ to $77.3 \%$. Perhaps disadvantage of low temperature could compel the microorganisms to get together as soon as possible, which was favorable for the metabolic transfer and exchange rate interspecies.

\section{IVCONCLUSIONS}

The low temperature could decrease COD removal efficiencies. But for higher influent flow (15-24L.h $\left.{ }^{-1}\right)$ (following higher OLR), the decreasing of COD removal efficiencies was not distinct with the operation temperature decreasing from $26^{\circ} \mathrm{C}$ to $15^{\circ} \mathrm{C}$. However, for low influent flow $\left(9 \mathrm{~L} . \mathrm{h}^{-1}\right)$ (following lower OLR), the decreasing extent of COD removal was high to $11 \%$ for $26^{\circ} \mathrm{C}$ and $15^{\circ} \mathrm{C}$. Although enhancing $V_{u p}$ could increase COD removal efficiency, the increasing quantity was comparatively limited. Thus, when using EGSB reactor to treat actual domestic wastewater at ambient temperature $\left(15{ }^{\circ} \mathrm{C}-26^{\circ} \mathrm{C}\right), 15-24 \mathrm{~L} \cdot \mathrm{h}^{-1}$ influent flow and $3.0 \mathrm{~m} \cdot \mathrm{h}^{-1} V_{u p}$ was suitable, only $0.5-0.8 \mathrm{~h}$ HRT was employed, and 80.2\%-82.3\% COD removal could attain.

At $26^{\circ} \mathrm{C}$, the SMA was not decreased. At $15^{\circ} \mathrm{C}$, the SMA was distinctly decreased, but which could resume at $35^{\circ} \mathrm{C}$.Low temperature would compel the microorganisms to get together as soon as possible. Compared with $26^{\circ} \mathrm{C}$, the average size of the granules was increased from $0.9 \mathrm{~mm}$ to $1.0 \mathrm{~mm}$ at $15^{\circ} \mathrm{C}$.

\section{ACKNOWLEDGEMENTS}

This research was supported by grants from the Shan-Xi province government (Province Natural Science Foundation of Shan Xi, NO. 2011011008-3; Province Key Technologies R \& D Program of Shan Xi, NO.20120313008-2) and grants from the Taiyuan city government (The star of science and technology special Project, NO.).

\section{REFERENCES}

[1] Tarek Sabry .Application of the UASB inoculated with flocculent and granular sludge in treating sewage at different hydraulic shock loads . Bioresource Technology.2008, 99: 4073-4077

[2] Lucas Seghezzo, Grietje Zeeman, Jules B. van Lier et al. A review: the anaerobic treatment of sewage in UASB and EGSB reactor. Bioresource Technology, 1998, 65(1): 175-190

[3] L.W. Hulshoff, S.I. de Castro, G. Lettinga, P.N.L. Lens, Anaerobic sludge granulation, Water Res. 2004, 38:1376-1389 
[4] C. Nicolella, M.C.M. van Loosdrecht, J.J. Heijnen.Wastewater treatment with particulate biofilm reactors. Journal of Biotechnology.2000,80:1-33

[5] Yi Jing Chan, Mei Fong Chong, Chung Lim Law, D.G. Hassell. A review on anaerobic-aerobic treatment of industrial and municipal wastewater. Chemical Engineering Journal, 2009,155:1-18

[6] State environmental protection administration of china. Water and wastewater monitoring and analytical methods. Beijing: China Environmental Science Press, 2004

[7] Kim W, Inge D B, Willy V. Oxygen-limited autotrophic nitrification-de-

nitrification (OLAND) in a rotating biological contactor treating high-sa-

linity wastewater. Wat. Res.2005,39:4512-4520 